\title{
The Influence of Fodder Additives in Feeds on the Production Performance and Egg Quality of Laying Quails
}

\author{
Teodor Ioan MĂLDĂRĂȘANU ${ }^{11 *}$, Aurel ŞARA ${ }^{13}$, Mihai BENȚEA ${ }^{1)}$ \\ 1) Faculty of Animal Science and Biotechnologies, University of Agricultural Sciences and Veterinary \\ Medicine Cluj-Napoca, 3-5Mănăştur Street, 400372 Cluj-Napoca, Romania \\ *Corresponding author, e-mail: maldarasanu_teodor@yahoo.com
}

Bulletin UASVM Animal Science and Biotechnologies 72(2) / 2015

Print ISSN 1843-5262; Electronic ISSN 1843-536X

DOI:10.15835/buasvmcn-asb:11460

\begin{abstract}
The research has been carried out on 99 laying quails, randomly distributed in 3 groups, each group consisting of 33 birds. Group 1 received the base diet supplemented with organic Selenium (Sel-Plex) 0.04\% + BioMos 0.12\%; group 2 received the base diet supplemented with organic Selenium (Sel-Plex) 0.04\% + Actigen 0.08, while the control group received the base diet, with no fodder additives. The experimental period was 18 weeks (from 5 weeks to 23 weeks of age). Individual weighing of quails was carried out at the beginning, in the middle and the end of the experimental period. During the experiment, a number of indicators were recorded: body mass evolution, mortality rate, laying intensity, mean egg weight, feed consumption/egg, the weight of the main structural components of eggs and their proportion, egg defects, egg chemical composition and the main physical and morphological indicators of egg quality. The combined use of feed additives (Sel-Plex + Bio-Mos and Sel-Plex + Actigen) led to positive results that confirm the positive influence of these additives, when used in the nutrition of laying quails.
\end{abstract}

Keywords: Actigen, Bio-Mos, Sel-Plex, nutrition, performances.

\section{INTRODUCTION}

The ban of various antibiotic based growth promoters, especially in Europe, underlined the need to develop alternative strategies to enhance productivity and animal health in intensive rearing systems, thus avoiding a significant increase of the production costs.

An alternative to antibiotic-based growth promoters was found in the use of organic additives. This class comprises, among others, of organic minerals like organic Selenium (Sel-Plex) and prebiotics (Bio-Mos and Actigen), all three additives being produced by the US based Alltech Company.

Organic Selenium, Sel-Plex, is obtained from a Sacharomyces cerevisiae strain, as selenomethionine. With a high mineral content, the fodder yeasts are very suitable for obtaining organic minerals. Thus, if a sulfur deficit is present in the culture medium, the yeasts have the capacity to incorporate Selenium as seleno-methionine and seleno-cysteine, in quantities much higher than their normal nutritive requirements; some strains of yeasts can produce up to $75 \%$ selenomethionine.

An important characteristic is that the animal organism absorbs and metabolizes selenomethionine in the same way as methionine.

Bio-Mosispartofthemannan-oligosaccharides category, being a derivative of mannans found on the surface of the yeast cell S. cerevisiae. Bio-Mos reduces the colonization of the gastro-intestinal tract by pathogens (Salmonella, Coliforms). The Gram-negative agents attach themselves to the 
Mos, instead of attaching to the epithelial cells of the intestine, thus going through the intestine without colonizing it (Şara, 2006).

Bio-Mos eliminates the pathogens from the intestinal tract by preventing the attachment of various micro-organisms that cannot station long enough to multiply and induce clinical disease symptoms (Şara and Bențea, 2012).

Actigen is a prebiotic containing mannanoligosaccharids, being a derivative of Bio-Mos, which is, in turn, a derivative obtained from the cellular wall of Saccharomyces cerevisiae; in other words, Actigen is a more concentrated form of BioMos.

Some research carried out on quails clearly indicates an increase in Selenium content of different tissues from the quails fed on organic Selenium as Sel-Plex (Karadaset et al., 2004b).

The supplementation of feeds destined for poultry, using organic Selenium (Sel-Plex), as reported by other researchers, led to the reduction of feed consumption (Sara and Bențea, 2012), an increase of the laying intensity and egg mass (Pan et al., 2004; Stanley et al., 2004; Şara et al., 2008), an improvement of the body mass (Pan et al., 2004) and a reduction in the specific consumption/egg, the feed efficiency being significantly increased (Neylor et al., 2000; Edens et al., 2001; Şara et al., 2008).

The positive effects of Bio-Mos in laying hens were described by other authors such as Gracia et al. (2004), Kocher et al. (2005), Dimovelis et al. (2004), Sara et al. (2006), who reported an increase in laying intensity and feed conversion after dietary supplementation using Bio-Mos. Other reported positive effects of Bio-Mos in laying hens were the improvement of the mean egg weight (Dimovelis et al., 2004; Stanley et al., 2004) and egg quality (Dimovelis et al., 2004; Sara et al., 2006) and the reduction of mortalities (Dimovelis et al., 2004; Kocher et al., 2005).

Lea et al. (2011), in an experiment carried out on laying hens, after supplementing the diet with Actigen, reported an increase of the body weight and the improvement of FCR. These results were also confirmed by Munyaka et al. (2011), who reported a decrease of mortalities and an enhancement of the immune system after dietary use of Actigen.

Stanley et al. (2004) studied the effects of BioMos and Sel-Plex, by themselves and combined, on egg production and quality in laying hens. The egg production of hens fed with Bio-Mos + Sel-Plex was significantly higher (90\%) compared to the control group (81.4\%). The eggs from the Bio-Mos + Sel-Plex group had an egg-yolk (20.68 g) and an egg-white (39.02 g) significantly larger compared to the control group $(18.12 \%$ and $35.51 \%$, respectively). The cholesterol concentration in the eggs from this group was also lower compared to the control group.

The results suggest the existence of a synergic effect between Bio-Mos and Sel-Plex regarding the egg production.

The aim of this research was to evaluate and emphasize the possible influence of the combined use of additives (Sel-Plex + BioMos and Sel-Plex + Actigen) administered in the feeds of laying quails, on production performances and egg quality parameters.

\section{MATERIALS AND METHODS}

The research was carried out on 99 laying quails, randomly distributed in 3 experimental groups, each group consisting of 33 birds. Group 1 received the base fodder supplemented with organic Selenium (Sel-Plex), 0.04\% + Biomos $-<0.12 \%$; group 2 was fed with the base fodder supplemented with organic Selenium 0,04\% + Actigen $0.08 \%$, the control group receiving only the base fodder. The experiment was carried out over a period of 18 weeks, from 28.05.2013 to 30.09 .2013 , from the age of 5 weeks to the age of 23 weeks. The laying quails were individually weighed at the beginning, in the middle and the end of the experimental period.

The three groups were housed in cages specifically designed for laying quails, with dimensions of $\mathrm{LxWxH}=90 \times 50 \times 25 \mathrm{~cm}$; the cages were set on the same height, receiving the same environmental and nursing conditions.

The air temperature was $23-24^{\circ} \mathrm{C}$ and was maintained at these levels using two fans and a heater connected to a programmable outlet set to start the heater when the temperature dropped below $23^{\circ} \mathrm{C}$.

The fodder administered to the laying quails had the following structure: corn $37.5 \%$, wheat $10 \%$, soybean meal $24 \%$, sunflower meal $13 \%$, corn gluten $2.5 \%$, vegetable oil $2.8 \%$, monocalcium phosphate $1.2 \%$, calcium carbonate $7.5 \%$, L-lysine $0.075 \%$, methionine $0.025 \%$,vitamin and mineral 
animal feed premix $1 \%$ and $\mathrm{NaCl} 0.4 \%$. This fodder represented the base fodder, being subsequently supplemented using the studied additives which constituted the experimental variable.

Water and feed were administered ad libitum in all groups used in this study.

The recorded data was statistically analysed using ANOVA by means of Tukey and Student tests, using the GraphPadInStat software, ver.3.10.

\section{RESULTS AND DISCUSSIONS}

The mean values recorded for the body mass evolution and the variability of this parameter in laying quails are shown in Table 2.

As shown in table 2, all three groups had similar initial weights (199.82 g - M, 199.42 L1E and 199.78 - L2E.) at the beginning of the experiment (age 5 weeks).

In the middle of the experimental period (age 14 weeks), the quails in group $1 \mathrm{E}$, which received a combination of organic Selenium $(0.04 \%)$ and Bio-Mos $(0.12 \%)$ had an average weight $6.91 \mathrm{~g}$ higher than the quails from the control group, the differences being non-significant, while the birds in group 2E, receiving the organic Selenium $(0,04 \%)$ and Actigen $(0,08 \%)$ combination, had a $24.76 \mathrm{~g}$ higher average weight, compared to the control group, the recorded differences being statistically distinctly significant.

At the end of the experimental period, the birds in group $1 \mathrm{E}$ showed an improvement of the body mass by $10 \mathrm{~g}$ compared to the control group, with non-significant differences. Group 2E showed an average weight of $271.56 \pm 4.19 \mathrm{~g}$, higher as compared to the control group (256.76 $\pm 4.02 \mathrm{~g})$. These improvements were also reported by Pan et al. (2004), when using organic Selenium, and by Lea et al. (2011) and Munyaka et al. (2011), after using the Actigen prebiotic.

Table 3 presents the effects of using combined additives (Sel-Plex + Bio-Mos, Sel-Plex +Actigen) in laying quails nutrition, on the main production and consumption indicators.

The combined use of Sel-Plex $(0.04 \%)+$ BioMos (0.12\%) and Sel-Plex (0.04\%) + Actigen $(0.08 \%)$ in laying quails had a positive effect on the production and consumption indicators, a positive influence being observed in the case of laying intensity and feed conversion for egg production.

The absolute laying intensity values recorded in the experimental groups $1 \mathrm{E}$ and $2 \mathrm{E}$ were $5.13 \pm 3.35 \%$ and $85.88 \pm 3.37 \%$, respectively, compared to the control group that showed a value of $77.01 \pm 3.64 \%$; the laying intensity was $10.54 \%$ higher in group 1E (Sel-Plex + BioMos) and 11.52\%

Tab. 1 The nutritive values of the base fodder

\begin{tabular}{lcccccccc}
\hline \multirow{2}{*}{$1 \mathrm{Kg}$} & $\begin{array}{c}\text { M.E. } \\
\text { feed }\end{array}$ & $\begin{array}{c}\text { C.P. } \\
(\mathrm{Kcal} / \mathrm{Kg})\end{array}$ & $\begin{array}{c}\text { Lysine } \\
(\%)\end{array}$ & $\begin{array}{c}\text { Methyonine } \\
(\%)\end{array}$ & $\begin{array}{c}\text { Met.+Cist } \\
(\%)\end{array}$ & $\begin{array}{c}\text { Tryptophan } \\
(\%)\end{array}$ & $\begin{array}{c}\text { Ca } \\
(\%)\end{array}$ & $\begin{array}{c}\mathrm{P} \\
(\%)\end{array}$ \\
\cline { 2 - 10 } & 2700 & 21.5 & 1.06 & 0.46 & 0.73 & 0.25 & 3.3 & 0.7 \\
\hline
\end{tabular}

Tab. 2. Body mass evolution in laying quails, throughout the experimental period

\begin{tabular}{|c|c|c|c|c|c|}
\hline Issue & Group & $\mathrm{n}$ & $\mathrm{X} \pm \mathrm{sx}$ & $\mathrm{s}$ & V\% \\
\hline \multirow{3}{*}{$\begin{array}{l}\text { Initial body mass } \\
\text { (age } 5 \text { weeks) }\end{array}$} & $\mathrm{C}$ & 33 & $199.82 \pm 5.72$ & 32.85 & 16.44 \\
\hline & L1E & 33 & $199.42 \pm 5.28$ & 30.33 & 15.21 \\
\hline & L2E & 33 & $199.78 \pm 4.93$ & 28.31 & 14.17 \\
\hline \multirow{3}{*}{$\begin{array}{l}\text { Body mass at the middle of the } \\
\text { experimental period } \\
\text { (age } 14 \text { weeks) }\end{array}$} & $\mathrm{C}$ & 33 & $252.03 \pm 5.79$ & 33.28 & 13.21 \\
\hline & L1E & 33 & $258.94 \pm 5.00$ & 28.73 & 11.10 \\
\hline & L2E & 33 & $276.79 \pm 3.84^{* *}$ & 22.03 & 7.96 \\
\hline \multirow{3}{*}{$\begin{array}{l}\text { Final body mass } \\
\text { (age } 23 \text { weeks) }\end{array}$} & $\mathrm{C}$ & 29 & $256.76 \pm 4.02$ & 23.93 & 8.86 \\
\hline & L1E & 32 & $266.75 \pm 4.85$ & 27.42 & 10.28 \\
\hline & L2E & 32 & $271.56 \pm 4.19 *$ & 23.70 & 8.73 \\
\hline
\end{tabular}

*- p<0.05- significant ; **- p<0.01- distinctly significant; C - control group; L1E - Sel-Plex+Bio-Mos, L2E - Sel-Plex+Actigen; X \pm SX- mean, sstandard deviation; V\%- variability coefficient. 
higher in group 2E (Sel-Plex + Actigen), compared to the control group.

The mean egg weight was $2.48 \pm 0.07$ for the control group, $12.61 \pm 0.6$ for group $1 \mathrm{E}$ and $12.76 \pm 0.07$ in group L2E, the only statistically significant difference being recorded between group $2 \mathrm{E}$ and the control group.

Regarding the mean daily mass-egg production, the highest value was recorded in group 2E (10.96g), 14.05\% higher than the control group, followed by group 1E (10.73g) which showed an $11.65 \%$ higher value compared to the control group (9.61g).

The mean feed consumption dropped from $29.23 \mathrm{~g}$ for the control group to $28.57 \mathrm{~g}$ in group $1 \mathrm{E}$, and $28.34 \mathrm{~g}$ in group $2 \mathrm{E}$.

At the same time, the feed conversion ratio and the average feed consumption/egg dropped $11.73 \%$ in group $1 \mathrm{E}(2.99 \pm 1.26 \mathrm{~g})$ and $13.92 \%$ in group $2 \mathrm{E}(32.17 \pm 1.01 \mathrm{~g})$, compared to the control group $(37.37 \pm 1.75 \mathrm{~g})$, the differences recorded between the experimental groups being statistically significant.

Improvements of the production and consumption indices in laying birds were also reported by other authors such as Şara and Bențea (2012), Pan et al. (2004) and Stanley et al. (2004) using organic Selenium (Sel-Plex), Kocher et al. (2005) using Bio-Mos and Lea et al. (2011) using Actigen.

Table 4 presents data regarding the weight of the main structural components of eggs, their proportions and the thickness of the egg shell.

As seen in table 4, all experimental groups showed similar values regarding the weight of the main structural components of eggs and their proportions, the differences recorded being statistically non-significant. The same trend was also recorded in the case of egg shell thickness.

The main egg quality indicators, including egg format index, egg volume, specific weight, egg white index, egg yolk index and the Haugh units, are presented in table 5.

The values recorded on the main quality indicators of eggs were improved, especially the egg format index, specific weight the yolk index, although the differences recorded between all the experimental groups were non-significant.

Significant differences were recorded in both the experimental groups compared to the control group regarding the egg volume and the Haugh units. Group $1 \mathrm{E}$ had an egg volume of $12.54 \pm 0.22 \mathrm{~cm}^{3}$, group $2 \mathrm{E} 12.66 \pm 0.31 \mathrm{~cm}^{3}$, while the control group only had an average egg volume

Tab. 3. The mean production and consumption indicators recorded for laying quails throughout the experimental period

\begin{tabular}{|c|c|c|c|c|}
\hline \multirow[b]{2}{*}{ Issue } & & \multicolumn{3}{|c|}{ Experimental groups } \\
\hline & & $\mathrm{C}$ & $\begin{array}{c}\text { L1E } \\
\text { (Sel-Plex+Bio-Mos) } \\
\end{array}$ & $\begin{array}{c}\text { L2E (Sel } \\
\text { Plex+Actigen) }\end{array}$ \\
\hline \multirow{2}{*}{ Body weight (g) } & Initial & $199.82 \pm 5.72$ & $199.42 \pm 5.28$ & $199.78 \pm 4.93$ \\
\hline & Final & $256.76 \pm 4.02$ & $266.75 \pm 4.85$ & $271.56 \pm 4.19^{*}$ \\
\hline \multicolumn{2}{|l|}{ Weight gain (g) } & 56.94 & 67.33 & 71.78 \\
\hline \multirow{2}{*}{ Laying intensity (\%) } & Absolute & $77.01 \pm 3.64$ & $85.13 \pm 3.35$ & $85.88 \pm 3.37$ \\
\hline & Relative & 100.00 & 110.54 & 111.52 \\
\hline \multirow{2}{*}{ Mean egg weight } & $\mathrm{g}$ & $12.48 \pm 0.07$ & $12.61 \pm 0.6$ & $12.76 \pm 0.07^{*}$ \\
\hline & $\%$ & 100 & 101.04 & 102.24 \\
\hline \multirow{2}{*}{$\begin{array}{l}\text { Daily mean mass-egg } \\
\text { production }\end{array}$} & $\mathrm{g}$ & 9.61 & 10.73 & 10.96 \\
\hline & $\%$ & 100 & 111.65 & 114.05 \\
\hline \multicolumn{2}{|c|}{ Daily average feed consumption (g) } & $29.23 \pm 0.25$ & $28.57 \pm 0.31$ & $28.34 \pm 0.32$ \\
\hline \multirow{2}{*}{$\begin{array}{l}\text { Average feed consumption / } \\
100 \mathrm{~g} \text { egg-mass }\end{array}$} & $\mathrm{g}$ & $298.99 \pm 15.20$ & $261.45 \pm 10.76^{*}$ & $252.15 \pm 9.17^{*}$ \\
\hline & $\%$ & 100 & 87.44 & 84.33 \\
\hline \multirow{2}{*}{ Feed conversion ratio / egg } & $\mathrm{g}$ & $37.37 \pm 1.75$ & $32.99 \pm 1.26^{*}$ & $32.17 \pm 1.01^{*}$ \\
\hline & $\%$ & 100 & 88.27 & 86.08 \\
\hline
\end{tabular}


of $11.82 \pm 0.18 \mathrm{~cm}^{3}$. The Haugh unit values varied from $95.01 \pm 1.09$ recorded in group $1 \mathrm{E}$ (SelPlex+Bio-Mos) and 95.46 \pm 0.66 in group 2E (SelPlex+Actigen) to $91.91 \pm 1.23$ recorded in the case of the control group.

A distinctly significant difference $(\mathrm{p}<0.01)$ was recorded for the egg white index, between the experimental group $2 \mathrm{E}(0.0974 \pm 0.0033)$ and the control group $(0.0816 \pm 0.0034)$.

The above mentioned results show that the combined use of additives (Sel-Plex+Bio-Mos and Sel-Plex+Actigen) in laying quails had a positive influence on some egg quality indicators recorded in this study.

Tab. 4. Weight of the main structural components of eggs, their proportions and the thickness of the egg shell, recorded at the end of the experimental period

\begin{tabular}{|c|c|c|c|c|c|}
\hline \multirow{2}{*}{ Issue } & & \multirow{2}{*}{$\mathrm{n}$} & \multicolumn{3}{|c|}{ Experimental groups } \\
\hline & & & $\mathrm{C}$ & $\mathrm{L} 1 \mathrm{E}(\mathrm{S}+\mathrm{B})$ & $\mathrm{L} 2 \mathrm{E}(\mathrm{S}+\mathrm{A})$ \\
\hline \multirow{2}{*}{ Mean egg weight (g) } & $\mathrm{g}$ & \multirow{2}{*}{20} & $12.745 \pm 0.281$ & $12.854 \pm 0.285$ & $13.085 \pm 0.251$ \\
\hline & $\%$ & & 100 & 100.90 & 104.23 \\
\hline \multirow{2}{*}{ Mean weight of egg yolk (g) } & $\mathrm{g}$ & \multirow{2}{*}{20} & $3.75 \pm 0,117$ & $3.78 \pm 0.086$ & $3.86 \pm 0.075$ \\
\hline & $\%$ & & 29.42 & 29.41 & 29.50 \\
\hline \multirow{2}{*}{ Mean weight of egg white (g) } & $\mathrm{g}$ & \multirow{2}{*}{20} & $7.39 \pm 0.164$ & $7.35 \pm 0.166$ & $7.79 \pm 0.161$ \\
\hline & $\%$ & & 58.05 & 57.17 & 58.10 \\
\hline \multirow{2}{*}{ Mean shell weight (g) } & $\mathrm{g}$ & \multirow{2}{*}{20} & $1.57 \pm 0.052$ & $1.73 \pm 0.079$ & $1.65 \pm 0.053$ \\
\hline & $\%$ & & 12.43 & 13.42 & 12.41 \\
\hline Mean shell thickness (g) & & 20 & $0.208 \pm 0.003$ & $0.215 \pm 0.002$ & $0.219 \pm 0.002$ \\
\hline
\end{tabular}

Tab. 5. The main physical and morphological indicators of egg quality

\begin{tabular}{|c|c|c|c|c|c|}
\hline Issue & Group & $\mathrm{n}$ & $\mathrm{X} \pm \mathrm{sx}$ & $\mathrm{s}$ & $\mathrm{V} \%$ \\
\hline \multirow{3}{*}{ Egg format index (\%) } & $\mathrm{C}$ & 20 & $78.00 \pm 0.47$ & 2.09 & 2.68 \\
\hline & L1E & 20 & $78.01 \pm 0.45$ & 2.01 & 2.58 \\
\hline & L2E & 20 & $78.79 \pm 0.62$ & 2.76 & 3.51 \\
\hline \multirow{3}{*}{ Egg volume $\left(\mathrm{cm}^{3}\right)$} & $\mathrm{C}$ & 20 & $11.82 \pm 0.18$ & 0.81 & 6.82 \\
\hline & L1E & 20 & $12.54 \pm 0.22^{*}$ & 0.99 & 7.88 \\
\hline & L2E & 20 & $12.66 \pm 0.31^{*}$ & 1.37 & 10.78 \\
\hline \multirow{3}{*}{ Specific weight $\left(\mathrm{g} / \mathrm{cm}^{3}\right)$} & $\mathrm{C}$ & 20 & $0.958 \pm 0.003$ & 0.02 & 1.72 \\
\hline & L1E & 20 & $0.959 \pm 0.003$ & 0.02 & 1.80 \\
\hline & L2E & 20 & $0.969 \pm 0.005$ & 0.02 & 2.44 \\
\hline \multirow{3}{*}{ Egg white index } & $\mathrm{C}$ & 20 & $0.0816 \pm 0.0034$ & 0.015 & 18.56 \\
\hline & L1E & 20 & $0.0879 \pm 0.0039$ & 0.017 & 19.82 \\
\hline & L2E & 20 & $0.0974 \pm 0.0033^{* *}$ & 0.015 & 15.04 \\
\hline \multirow{3}{*}{ Egg yolk index } & $\mathrm{C}$ & 20 & $0.4785 \pm 0.0106$ & 0.047 & 9.87 \\
\hline & L1E & 20 & $0.4898 \pm 0.0066$ & 0.029 & 6.02 \\
\hline & L2E & 20 & $0.4946 \pm 0.0065$ & 0.029 & 5.84 \\
\hline \multirow{3}{*}{ Haugh units (H.U.) } & $\mathrm{C}$ & 20 & $91.91 \pm 1.23$ & 5.48 & 5.97 \\
\hline & L1E & 20 & $95.01 \pm 1.09 *$ & 4.89 & 5.15 \\
\hline & $\mathrm{L} 2 \mathrm{E}$ & 20 & $95.46 \pm 0.66^{*}$ & 2.97 & 3.11 \\
\hline
\end{tabular}


Tab. 6. The effects of the combined additives (Sel-Plex+Bio-Mos and Sel-Plex+Actigen) on egg shell exterior and mortality rates of laying quails, recorded throughout the experimental period

\begin{tabular}{|c|c|c|c|}
\hline \multirow[b]{2}{*}{ Issue } & \multicolumn{3}{|c|}{ Experimental groups } \\
\hline & Control & $\begin{array}{c}\text { Group } 1 \\
\text { (Sel-Plex 0.04\% } \\
+ \\
\text { BioMos0.12\%) }\end{array}$ & $\begin{array}{c}\text { Group } 2 \\
\text { (Sel-Plex } 0.04 \% \\
+ \\
\text { Actigen } 0.08 \% \text { ) }\end{array}$ \\
\hline Normal eggs (\%) & 95.89 & 98.64 & 98.77 \\
\hline Broken eggs (\%) & 1.39 & 0.39 & 0.42 \\
\hline Cracked eggs (\%) & 1.00 & 0.37 & 0.36 \\
\hline $\begin{array}{c}\text { Eggs with wrinkled shells, } \\
\text { rugosity (\%) }\end{array}$ & 0.84 & 0.37 & 0.25 \\
\hline Eggs with soft shells (\%) & 0.78 & 0.23 & 0.17 \\
\hline Completely white eggs (\%) & 0.10 & 0 & 0.03 \\
\hline Mortality rate (\%) & 12.12 & 3.03 & 3.03 \\
\hline
\end{tabular}

The effects of the combined additives on egg shell exterior and mortality rates of laying quails, recorded at the end of the experimental period, are presented in table 6.

The number of eggs showing shell defects (broken eggs, cracked eggs, eggs with wrinkled shells, eggs with soft shells or completely white eggs) was much lower in the experimental groups $1 \mathrm{E}$ and $2 \mathrm{E}(1.36 \%$ and $1.23 \%)$ compared to the control group (4.11\%). Regarding the mortality rates, the control group showed the highest values $(12.12 \%)$, groups $1 \mathrm{E}$ and $2 \mathrm{E}$ showing much lower mortality rates $(3.03 \%)$.

Both the lower percentage of eggs with defects and the reduction in mortalities confirm the positive influence of the combinations used, when aiming at better productions in terms of quality and health.

\section{CONCLUSIONS}

The combined use of organic Selenium (SelPlex) and Actigen led to an improvement of the body weight throughout the experimental period, the difference between this group and the control group being significant. The Sel-Plex and Bio-Mos combination also had positive effects on the body weight, the difference recorded being statistically non-significant.

The use of organic Selenium, with both Bio-Mos and Actigen, in laying quails' diets led to the improvement of the main production and consumption indicators, all through the experimental period.
No significant differences were recorded, after administering additives combination, regarding the main structural components of eggs, their proportion and the thickness of the egg shell, when comparing all the experimental groups.

The supplementation of diets using SelPlex+BioMos led to the improvement of the egg volume and Haugh unit; the use of Sel-Plex+Actigen had positive effects on the egg volume, egg white index and Haugh unit.

The combination of Sel-Plex with Bio-Mos and Actigen, administered in diets for laying quails, led to the reduction of the recorded egg defects, the mortality rate also showing a decrease as a result of additive supplementation.

The results confirm the positive influence of organic Selenium and BioMos or Actigen combinations on the production performances and egg quality in laying quails. Based on these results, we recommend the use of these organic additives in quails used for egg production.

\section{REFERENCES}

1. Dimovelis P, Christaki E, Tserveni-Goussi A, Spais AB (2004) Performance of layer hens fed a diet with mannanoligosaccharides from Sacharomyces cerevisiae (BioMos). In 'World Poultry Congress'. Istanbul, Turkey pp. 1-4. (WPSA)

2. Edens FW, Parkhurst CR, Havenstein GB, Ferket PR, Sefton $\mathrm{AE}$ (2001). Influence of selenium yeast (Sel-Plex) on performance and carcass yield of broiler males grown in a cage environment. Poultry Science 79 (Suppl. 1): 55

3. Garcia M, Cachaldora P, Tucker LA, Baucells F, Medel $P$ (2004) Effect of mannan oligosaccharides supplementation to laying hen diets. Poultry Science 83, 397. 
4. Karadas E, Surai PE, Yaroshenko FO, Villaverde C, Bosica E, Sparks, NHC (2004b). Effect of long-tem consumption of organic selenium by quail on selenium concentration in egg yolk and quail tissues. Book of Abstracts XXII World's Poultry Congress, 8-13 June, 2004, Istanbul, Turkey, p.521

5. Kocher A, Garcia P, Tucker LA (2005) Effects of Bio-Mos for laying hens 20-52 weeks under commercial conditions. World Poultry Science Association, 15th European Symposium on Poultry Nutrition, Balatonfured, Hungary , 25-29 September

6. Lea HK, Kay L and Burton EJ (2011) Performance and gut health of poultry in the post-antibiotic era when feeding a novel yeast cell wall component, $27^{\text {th }}$ International Symposium "Science and Technology in the Feed Industry".

7. Munyaka P, Echeverry HM, Yitbarek A, Einarson M, Sharif S, Guenter W, House JD, Rodriguez-Lecompte JC (2011) Toll-like receptor and cytokine profile of chickens supplemented with Actigen ${ }^{\mathrm{TM}}, 27^{\text {th }}$ International Symposium "Science and Technology in the Feed Industry".

8. Neylor AJ, Choct M, Jacques KA (2000). Effects of selenium source and level on performance and meat quality in male broilers. Poultry Science 79 (Suppl) 117

9. Pan EA, Rutz F, Dionello NJL, Anciuti MA and Da Silva (2004) Organo selenium effect on the performance of laying hens, Proceedings of the $20^{\text {th }}$ Annual Symposium May 24-26, (Supplement 1)

10. Pan EA, Rutz F, Dionello NJL, Anciuti MA and Da Silva RR (2004) Performance of brown egg layers fed diets containing organic selenium (Sel-Plex). Nutritional Biotechnology in the Feed and Food Industry. Proceedings of the $20^{\mathrm{th}}$ Annual Symposium (Suppl. 1), May 22-26, 2004, Lexington, Kentucky, USA, p. 18

11. Stanley V.G., V.Yancy, C. Gray, F.W. Krueger and A.E. Sefton (2004) Organo selenium effect on the performance of laying hens, Proceedings of the $20^{\text {th }}$ Annual Symposium May 24-26, 2004 (Supplement 1)

12. Şara A (2006) Nutrețurile și utilizarea lor în hrana animalelor, Ed. Risoprint, Cluj-Napoca, 198-201;

13. Şara A. și M. Bențea, 2012, Nutrețurile, caracteristici nutritive şiutilizare, Ed. Risoprint, Cluj-Napoca, 150-153;

14. Şara A, Bențea M, Odagiu A, Pantă L (2008) Effects of the organic selenium (Sel- Plex) administered in laying hens' feed in second laying phase on production performances and the eggs quality. Buletin USAMV- Animal Science and Biotechnologies, 65 (1-2)/2008 ISSN 1843- 5262, Electronic ISSN 1843- 536X, p.83- 87. 